\title{
Mooie mensen en middeleeuwse dokters
}

Het tijdvak middeleeuwen staat niet bekend om zijn effectieve gezondheidszorg en evenmin kennen we de periode als één met veel aandacht voor fysieke schoonheid. Toch waren middeleeuwers zelf over het algemeen best tevreden over de kennis van hun geleerde dokters, afgezien van incidenteel geklaag. Ook legden zij een duidelijke voorkeur voor bepaalde uiterlijke kenmerken aan de dag. Omdat veel van de bewaard gebleven middeleeuwse teksten door monniken zijn geschreven, en vooral aandacht voor het geestelijke tentoonspreidden, valt die voorkeur misschien niet onmiddellijk op. Maar zelfs een middeleeuwse monnik als Hugo van Fouilloy kon moeiteloos over de ideale vrouwenborsten spreken:

'mooi zijn de borsten die een beetje vooruitsteken en niet te veel opbollen en niet vrijelijk heen en weer golven, maar licht ingesnoerd zijn; vastgedrukt, maar niet neergedrukt'.

Dit alles naar aanleiding van het Bijbelse Hooglied. Ook voor mannen bestond in de middeleeuwen een duidelijk schoonheidsideaal. In ridderromans bijvoorbeeld werd het uiterlijk van de jonge held meestal uitputtend besproken. Parzival kwam aldus een stad binnen gereden:

'De nobele krijger legde één been voor zich op het paard; twee zomerlaarsjes droeg hij aan zijn blote benen. Zijn mond, als een robijn zo rood, glansde als vuur - volle lippen had

\author{
hij, en volstrekt geen smalle. Schoon \\ was zijn ganse lichaam.'
}

De middeleeuwse schoonheidsidealen van mannen en vrouwen verschilden van elkaar in hun functie en effect, net als tegenwoordig. Sociale status was nauw verbonden met de ideaalbeelden. En ook in de geneeskunde waren de beelden terug te vinden.

Als middeleeuwse vrouwen mooi wilden zijn, kostte dat veel werk, tijd en geld. Het ideale uiterlijk van de vrouw bestond uit een onmogelijke combinatie van kenmerken, zodat het gecreëerd moest worden, en niet zomaar van nature kon bestaan. De brede heupen van de mooie middeleeuwse vrouw waren opvallend, net als haar bolle onderbuik. Schilders en dichters brachten die samen met lange, rechte benen en een smal bovenlichaam, de borsten vlak onder de tengere schouders. Geen wonder dat middeleeuwse dames korsetachtige kledingstukken droegen om hun borsten omhoog te duwen, en hun bovenlichaam te versmallen. Voor de begerenswaardige bolle buik en brede heupen konden ze vullingen dragen onder hun zware rokken, of de plooien van hun kleed zó schikken dat ze een fraai gewelfd onderlichaam suggereerden. Dat de schoonheid van de dame statusgebonden was, bleek niet alleen uit haar gekleurde toiletten, die afstaken tegen de grauwe kleren van de doorsnee middeleeuwse. Een blanke huid vormde ook een nadrukkelijk onderdeel van de schoonheidscanon van de dame. Dat is overigens zo gebleven tot werkende mensen hun arbeid 
voornamelijk in fabrieken en kantoren gingen verrichten, en daardoor niet langer bruinverbrand waren, maar bleek.

Middeleeuwse medici pikten nu en dan een graantje mee van de vrouwelijke schoonheidsdrang, zo lijkt het. Avicenna's Canon, een veelomvattende medische encyclopedie, bevatte een deel met adviezen voor schoonheidsbehandelingen. Ook teksten die speciaal vrouwen en vrouwengeneeskunde behandelden, bevatten vaak schoonheidsremedies. Hoe de huid te witten, sproeten te bleken, het haar in de zon op te lichten, de haargrens te verhogen, de wenkbrauwen te verplaatsen, de tanden helder te maken, een prettige geurende adem te verwerven: het was allemaal te vinden. Menige dokter zal gewapend met deze kennis zijn vrouwelijke patiënten hebben geholpen om op hun voordeligst voor de dag te komen.

Het mannelijke schoonheidsideaal in de middeleeuwen was minder arbeidsintensief dan het vrouwelijke, maar minstens zo dun gezaaid. Jeugd en welvaart waren absolute voorwaarden, want de mooie man was jong en hoofs. Zijn lichaam was vlezig en weldoorvoed, zijn huid blank met roze, zijn kleding kleurig en overdadig - een pluim op de hoed mocht niet ontbreken. Dit schoonheidsideaal voor de man was ook nauw verweven met het middeleeuwse wereldbeeld. Dat kon gemakkelijk, omdat het mannelijke lichaam de maatstaf was in het middeleeuwse denken over leven en gezondheid. De jeugdige, hoofse man met pluim op de hoed kon fungeren als de typische beeltenis van de levensfase van de adolescentie, van het warmbloedige temperament, en van de hoofdzonde wellustigheid. Ook kon het verwijzen naar de lente en de planeten Venus - van de liefde - en Jupiter, de oppergod. Binnen de bete- kenisvolle biologie van de middeleeuwen werd de mooie man tot een symbool voor jeugd, zinnelijkheid en welvaart. Zo'n man hoefde niet te werken voor schoonheid, maar belichaamde die, als vanzelf, gewoon door wie hij was.

Middeleeuwse medici waren zeker bekend met het ideaal van de mooie man. Ze bespraken de aantrekkelijke vlezigheid van mannen met het bloedige temperament in hun traktaten. Ook roemden ze de schoonheid van jonge mannen, in de levensfase adolescentie. Toch namen ze het ideaal van de schoonheid niet klakkeloos over. Medici streefden naar gezondheid. Ze beschreven hoe een overmaat aan bloed kon leiden tot pussende zweren en rottende koortsen. Een volmaakt gezonde mens lees: man - werd niet overheerst door bloed, maar beschikte over dat vocht in de juiste mate. En adolescenten waren zeker mooi, maar ook onrijp, impulsief, en veel te vochtig. Middeleeuwse medici hadden als ideaal de volwassen man van ongeveer vijfendertig jaar. Minder fraai dan de jongelingen, maar in de kracht van zijn leven, en in potentie gezonder dan wie ook. En terwijl de artsen ijverden om hun patiënten zoveel als mogelijk van deze gezondheid te brengen, verdienden ze graag wat bij met een schoonheidsbehandeling nu en dan. Het trekken van parallellen met het heden omtrent deze onderwerpen laat ik graag aan de lezer over.

Karine van 't Land

De auteur:

Karine van 't Land is arts en historica. Ze werkt aan een proefschrift over het lichaam in verandering in de middeleeuwse geneeskunde aan de Radboud Universiteit Nijmegen. Zij is ook voorzitter van de Medisch-historische Club te Nijmegen, zie www.umcn.nl/mhcn. 